\title{
AC 2010-893: LEVERAGING THE UNIQUE CHARACTER OF A GENERAL ENGINEERING PROGRAM TO ENHANCE STUDENTS' ENTREPRENEURIAL MINDSET
}

Randall Brouwer, Calvin College

Steven VanderLeest, Calvin College

Paulo Ribeiro, Calvin College

Robert Medema, Calvin College 


\title{
Leveraging the Unique Character of a General Engineering Program to Enhance Students' Entrepreneurial Mindset
}

\begin{abstract}
The General Engineering degree provides a unique foundation to connect engineering with business and entrepreneurship. A significant portion of engineering students are interested in aspects of entrepreneurship which provides a springboard to engage the student's vision and imagination for better business education and better engineering education. This paper will first discuss recent curricular changes to our BS in Engineering degree, partly sponsored by a Kern Entrepreneurship Education Network (KEEN) grant, intended to enhance engineering students' understanding of business practices, societal needs, and engineering solutions. Initial changes focused on the "endcaps" of our first-year and senior-year courses. Based on those results, an extension of the changes throughout the curriculum may be implemented. Secondly, we identify some distinct characteristics of the general engineering curriculum that provide a fertile ground for this type of integrative, multidisciplinary work to be carried out. The learners within this context are often driven by a need to understand the "why" before they can be engaged on the "what" and "how" of engineering. The justification and explanation for technical topics and concepts are embedded in the broader context provided by a general engineering education. Finally, the paper concludes with an initial assessment of results and plans for expanding the business topics into intermediate engineering courses.
\end{abstract}

\section{Introduction: Why is this subject interesting and important?}

The multidisciplinary approach of general engineering programs (a distinct category of engineering degrees that ABET accredits without program-specific criteria) provides a particularly good foundation for entrepreneurial education. First, the breadth of these programs is more contextual than more narrowly defined engineering degrees. That context encourages students to "connect the dots", taking a systems approach that applies knowledge from one context to another domain. Although occasionally a new idea comes completely formed without a prior version, most new inventions take existing ideas and combine them in new ways. A contextual education encourages creative, systems level thinking that forms fertile ground for combining technical design, business, and entrepreneurship. Second, general engineering programs are typically less regimented and thus more flexible, allowing them to address entrepreneurship in a variety of ways. They can add entrepreneurial content to the curriculum within specific courses or introduce entirely new courses. Third, faculty in general engineering programs come from multiple engineering disciplines and tend to be entrepreneurial themselves when it comes to curricular change and reform. Fourth, students in general engineering programs tend to be multidisciplinary and multifaceted in their academic ambitions. These students selected a general engineering degree because they see the world from a systems perspective, a contextual perspective. They want to see the big picture and make a difference in the world. They are a receptive audience for entrepreneurial approaches.

Engineering students in any program, whether general or disciplinary-specific, can benefit from learning some of the concepts of entrepreneurship. The students in our engineering classes are 
eager to learn about entrepreneurial opportunities and ideas. A recent survey ${ }^{1}$ of undergraduate engineering students at five different schools showed that most (82\%) were interested in pursuing some form of entrepreneurship after graduation. Students want to know how to take their ideas and get them into the marketplace. They want to use their engineering skills to help real people with real problems (and they see entrepreneurship as a means to that end). They understand that competing for engineering projects in a global context requires not only strong technical knowledge, but also business acumen. This strong interest translates into engagement. Students learn best when they are engaged with the material. Entrepreneurship provides the bridge between engineering and business. That connection provides value in both directions, improving the student's understanding of both. In terms of Bloom's taxonomy of cognitive learning, entrepreneurship can move a student from simple knowledge and comprehension levels to the greater depths of application, analysis, and synthesis. Finally, because engineering is a challenging, rigorous program, students need a vision of themselves in the future to give them the stamina and courage to persevere. Entrepreneurship provides that vision so that they have an end goal worth pursuing to sustain them through their engineering education.

Having established the importance of entrepreneurship as part of an engineering education and the particular suitability of a multidisciplinary, general engineering curriculum for tacking entrepreneurial concepts, the remainder of this paper looks at some models for curriculum reform with an eye on entrepreneurship (in the form of a brief literature review) and then explores the entrepreneurship initiatives recently undertaken in the engineering program at Calvin College.

\section{Literature Review}

Who is providing entrepreneurship education within an engineering curriculum? A huge number of engineering programs provide some type of entrepreneurship education. In their survey of six programs at large universities in the United States, Terri Standish-Kuon and Mark Rice ${ }^{2}$ note the rapid rise of entrepreneurship programs from only 16 in 1970 to over 400 at the time of their publication in 2002. They found that already tight curricula were the most common hurdle to adding entrepreneurship topics to a program. On the positive side, a number of factors supported addition of entrepreneurship, such as passionate internal champions, financial support, along with internal and external networking. In reviewing the data from their studies at the six locations, they found "five categories of actions define entrepreneurship education in general: (1) developing intellectual content, including scholarly research; (2) gaining institutional acceptance, with attention to curricular, structural and fiscal issues; (3) engaging students and alumni; (4) building relationships with the business community; and (5) showcasing success." p. 34. Standish-Kuon and Rice chose not to distinguish the models by whether the content counted towards a degree. They found three models, with the most significant discriminator being the location within the university: (a) the business school, (b) the engineering school, or (c) collaboration between the two.

Streeter and Jaquette ${ }^{3}$ looked at the spread of entrepreneurship education beyond business and engineering, dividing all approaches into two types: "If the program is intended to infuse the institution with entrepreneurship education, we call it a university-wide program. Next, we examine the location of the faculty and teachers to determine if it is a magnet or a radiant program. If the program draws students into courses located in the business and/or engineering 
schools and taught by engineering and/or business faculty, then it is a single or multiple magnet program.” p. 55.

Rather than using a top-down structural model of programs that distinguishes by the location of the administrator of the program as both the Standish-Kuon and Streeter papers explore, in this paper we will use a bottom-up categorization, distinguishing by the location of entrepreneurship teaching within the engineering curriculum. Similar to other curricular reform efforts (such as drives to improve written or spoken communication, or math skill enhancement), the usual suspects arise as alternative approaches to providing entrepreneurially-related content or entrepreneurially-related experiences to education:

- Micro-insertion: Add content/experience to existing courses in curriculum

- Macro-insertion: Add new courses to curriculum

- Overhaul: Complete reworking of curriculum to include new content/experience

- Parallel: Provide content/experience as an elective or minor that is not required of all

The first three approaches attempt to provide entrepreneurial education to all engineering students in the program. Since these programs are often very full already, the school must make a trade-off in material, squeezing the new content in (and presumably squeezing something else out). The last approach drops a comprehensive requirement, providing the entrepreneurial content on top of the full engineering content. The literature provides many examples of each of these approaches, a few of which we provide here. Table 1 summarizes some of the distinguishing characteristics of curriculum reform, hinting at a taxonomy of sorts.

A Stanford survey ${ }^{4}$ found that amongst faculty teaching in around 40 entrepreneurship programs, the majority (58\%) were interested in incorporating new entrepreneurship educational resources into existing courses. The Stanford team went on to create an on-line resource to provide supplemental materials for just these faculty pursuing a micro-insertion model of curricular reform for entrepreneurship in engineering education.

Wang and Kleppe ${ }^{5}$ report on how the University of Nevada at Reno implemented a specialized senior capstone course that used NCIIA Entrepreneurship "E-Teams" with collaboration from MBA students from the business school. This course is part of the degree program, with adaptations for the new entrepreneurial content. Brown University ${ }^{6}$ inserted two new courses into their engineering curriculum, where student teams work with managers from industry to develop seed ideas into a business plan and prototype. This paper also points out a number of useful distinguishing characteristics of curriculum approaches, some of which we have used in our summary table.

Ohland $^{7}$ presents a vertically integrated approach used at North Carolina State University that places senior engineering students in leadership roles on teams of students that include sophomore and junior engineering members. The seniors earn credit toward their capstone design requirement (thus this adapts an existing course, but in some respects adds a course to the program). The paper also describes a two-course sequence at University of Florida that was added to the curriculum (but not required) and an adapted senior design course at University of 
North Carolina at Charlotte that incorporated industry-generated project ideas for multiple engineering disciplines.

Table 1: Example Entrepreneurship in Engineering Curriculum Models

\begin{tabular}{|c|c|c|c|c|c|c|c|}
\hline & $\begin{array}{l}\text { Curricular } \\
\text { Model }\end{array}$ & $\begin{array}{l}\text { Source of } \\
\text { Ideas }\end{array}$ & $\begin{array}{l}\text { Open to } \\
\text { non-engr } \\
\text { students? }\end{array}$ & $\begin{array}{l}\text { Part of } \\
\text { major } \\
\text { degree? }\end{array}$ & $\begin{array}{l}\text { Part of } \\
\text { minor }\end{array}$ & $\begin{array}{l}\text { Involve } \\
\text { business } \\
\text { school? }\end{array}$ & $\begin{array}{l}\text { Adapts } \\
\text { senior } \\
\text { capstone }\end{array}$ \\
\hline Brown $\mathrm{U}^{6}$ & $\begin{array}{l}\text { Macro- } \\
\text { Insertion }\end{array}$ & Industry & $Y$ & $\mathrm{~N}$ & & $\mathrm{~N}$ & $\mathrm{~N}$ \\
\hline $\begin{array}{l}\text { U of } \\
\text { Nevada- } \\
\text { Reno }^{5}\end{array}$ & $\begin{array}{l}\text { Micro- } \\
\text { Insertion }\end{array}$ & Students & $Y$ & $\mathrm{Y}$ & & $\mathrm{Y}$ & $Y$ \\
\hline $\begin{array}{l}\text { North } \\
\text { Carolina } \\
\text { State } \mathrm{U}^{7}\end{array}$ & $\begin{array}{l}\text { Micro- } \\
\text { Insertion, } \\
\text { Macro- } \\
\text { Insertion }\end{array}$ & Students & $\mathrm{N}$ & $\mathrm{Y}$ & & $\mathrm{N}$ & $Y$ \\
\hline $\begin{array}{l}\text { U of } \\
\text { Florida }^{7}\end{array}$ & Parallel & Industry & $Y$ & $\mathrm{~N}$ & & $Y$ & $\mathrm{~N}$ \\
\hline $\begin{array}{l}\text { U of } \\
\text { North } \\
\text { Carolina } \\
\text { at } \\
\text { Charlotte }^{7}\end{array}$ & $\begin{array}{l}\text { Micro- } \\
\text { Insertion }\end{array}$ & Industry & $\mathrm{N}$ & $Y$ & & $\mathrm{~N}$ & $Y$ \\
\hline $\begin{array}{l}\text { Michigan } \\
\text { Tech U }^{8}\end{array}$ & Parallel & $\begin{array}{l}\text { Industry, } \\
\text { faculty }\end{array}$ & $Y$ & $\mathrm{~N}$ & $\mathrm{Y}$ & $Y$ & $\mathrm{~N}$ \\
\hline $\begin{array}{l}\text { Illinois } \\
\text { Inst of } \\
\text { Tech }^{9}\end{array}$ & Parallel & $\begin{array}{l}\text { Industry, } \\
\text { faculty }\end{array}$ & $\mathrm{Y}$ & $\mathrm{Y}$ & $\mathrm{Y}$ & $\mathrm{Y}$ & $Y$ \\
\hline $\begin{array}{l}\text { Rowan } \\
\mathrm{U}^{10}\end{array}$ & $\begin{array}{l}\text { Overhaul, } \\
\text { Parallel }\end{array}$ & $\begin{array}{l}\text { Industry, } \\
\text { faculty, } \\
\text { students }\end{array}$ & $\mathrm{N}$ & $\mathrm{Y}$ & $\mathrm{Y}$ & $\mathrm{Y}$ & $\mathrm{N} / \mathrm{A}$ \\
\hline $\begin{array}{l}\text { Olin } \\
\text { College }\end{array}$ & $\begin{array}{l}\text { Micro- } \\
\text { Insertion, } \\
\text { Macro- } \\
\text { Insertion, } \\
\text { Parallel, } \\
\text { Overhaul }\end{array}$ & Industry & $\mathrm{N}$ & $\mathrm{Y}$ & $Y$ & $Y$ & $Y$ \\
\hline
\end{tabular}

At Michigan Tech, the Enterprise program provides course credit to students who participate in interdisciplinary projects, often with an entrepreneurial focus. These course credits can apply to an Enterprise Concentration or Enterprise Minor. ${ }^{8}$ The Illinois Institute of Technology (IIT) has a program called Interprofessional Projects Program (IPRO) and requires engineering students to participate in at least two interdisciplinary design projects through that program. The Entrepreneurial Projects Program (EnPRO) expands IPRO with entrepreneurially-focused projects. ${ }^{9}$ Both universities have made sure the team-based projects are highly multidisciplinary. 
The engineering program at Rowan University was started in 1992 with an emphasis on entrepreneurship ${ }^{10}$, including a technology entrepreneurship concentration as a collaboration between the engineering and business schools. Olin College ${ }^{11}$ is another example of a "fresh start" engineering curriculum with a heavy entrepreneurship emphasis. Their program infuses entrepreneurship at multiple levels, including micro-insertion in a number of required engineering courses, macro-insertion of whole courses that are required, and elective courses that form minors or concentrations.

\section{Our Approach}

\section{A. Calvin College Engineering Program Overview}

The four-year BSE program at Calvin College was intentionally designed as a general engineering program. The philosophy behind the engineering program is that graduating engineers are best able to serve when they are able to make engineering decisions from a broad perspective which includes an understanding of the various engineering disciplines, a working knowledge of the fundamental math and science principles, and an understanding of the context of the societal needs which are being addressed. Engineers educated with a narrow technical curriculum will not be as prepared to make important design decisions.

The first two years of the program are common for all students and cover much of the math, science, and fundamental engineering courses. The final two years of the program are focused on discipline-specific engineering courses and a capstone design course. Non-technical general education courses are uniformly distributed throughout the curriculum. Approximately $25 \%$ of the curriculum requirements are non-technical (general education) courses and another $25 \%$ are in foundational math and science courses. Interdisciplinary and fundamental engineering courses fill $20 \%$ of the requirements and discipline-specific engineering courses cover the remaining $30 \%$ of the requirements.

In recent years, engineering education has moved in the directions of collaborative and experiential learning. In addition, innovation and entrepreneurship have become common themes on engineering campuses as many schools have developed entrepreneurial minors and programs in response to interest from students in those topics. Although our program has been fully involved in collaborative and experiential education for many years, entrepreneurship is a fairly new concept on our campus.

Based on current student assessment, FE exam results, and feedback from alumni, we find that our engineering program prepares our students well for entry-level positions, licensure, and project/team management responsibilities. In general, the program is on the right track;

however, we have recent feedback that our students and alumni have been less able to apply business principles to the work they are doing. Many of our alumni have been moving into project and team management roles and some have specifically communicated that they wish they had been able to take more business courses while a student. Additionally, our engineering industrial advisory council has been doing assessments of the final designs from our capstone course. They have provided feedback indicating that our students are slightly weak in doing cost analyses and applying business fundamentals to their projects. Furthermore, we frequently see incoming students eager to find out more about entrepreneurship. Thus, we see a need for 
improving our students' ability to apply business knowledge and see engineering problems from an entrepreneurial mindset.

\section{B. $\quad$ Funding Timeline}

One of the first steps in our effort to address the above concerns was to apply for a grant from NCIIA (National Collegiate Inventors and Innovators Alliance) to fund the formation of a faculty/staff reading group focused on entrepreneurship and to fund our campus' first ever business plan competition. We were able to successfully apply for a small grant and began those two activities. The reading group provided some internal champions to continue pushing for entrepreneurism in the curriculum. At approximately the same time, we were approached by the Kern Family Foundation and asked to apply for a curriculum revision grant. The goal of the foundation's KEEN (Kern Entrepreneurial Education Network) grant program is to assist private schools that have engineering programs with curriculum adjustments to help all engineering students learn to think with an entrepreneurial mindset when addressing engineering problems. Currently, there are more than 20 schools in the network.

During 2007, we applied and were awarded a Phase I grant from the Kern Family Foundation. The focus of this grant project was to 1) continue the programs begun with the first NCIIA grant, 2) make curricular changes to a few courses, specifically our first-year introduction to engineering course and our senior-level business for engineers course, and 3) develop a new January-term course on managing innovation. Much of the funding provided stipend support for faculty making the changes to those courses. In 2009, we applied for a second phase grant from the Kern Family Foundation. The focus of this grant is 1) the continuation of previously begun activities, 2) further changes to some of the courses already modified, 3) changes to additional courses, and 4) faculty development activities.

\section{Curriculum Enhancements}

With support from the KEEN grant, we made changes to several courses throughout the curriculum (and more changes are planned). The goal of these changes is not to make entrepreneurs out of all of our engineering students. Instead, we hope to develop in our students some of the traits that are often associated with entrepreneurs but are also needed in $21^{\text {st }}$ century engineers. These changes follow the model of micro-insertions in a planned way across the curriculum. Since these changes occur in courses required of all engineering students, including the senior design capstone course, they are not considered "parallel" to the engineering program as would be the case of a entrepreneurial minor or concentration. The changes are detailed below.

Students begin the engineering program with an "Introduction to Engineering" course. Along with the typical introductory topics, we have added an introduction to business basics, the importance of assessing costs properly, the time value of money, budgeting, the role of intellectual property (specifically, patents), the needs of the customer, the mindset of an entrepreneur, and entrepreneurial case studies. Some future goals for the course are to have students develop a business plan related to their service-learning design project and to link the course with a written-rhetoric course from their general education requirements. Since 
communication skills are vital for engineers, we plan to partner with colleagues in the English department to guide our students into better understanding the nuances of technical writing.

Senior students take a course called "Business Aspects for Engineers." This course was originally designed to cover the basics of business finance, marketing, accounting, and management. In recent years, the faculty teaching the course have incorporated a business plan development and presentation requirement into the course and have weaved the topics of the course into the development of the business plan. Since most of the students concurrently are taking their capstone design course, the business plans are required to tie into their senior design projects. Such a linking of the business and senior design courses drives home the importance of the business side of engineering. Students are required to view their design projects from an enterprise perspective. The necessity of producing, pricing and marketing products and services with a profit objective for sustainability is emphasized. Students are also instructed in the basics of organization financing, capital budgeting and interpretation of financial statements. Management principles are taught from the perspective of servant leadership. Assessment information to date has shown that the addition of the business plan has been very successful and helpful for our students. Since the current size of two semester hours is fairly limiting, we are looking at options for expanding the course.

Calvin College has been seriously looking at energy and sustainability issues in recent years. A large variety of small-scale projects have been worked on as a part of certain courses, as part of selected senior design projects, and as projects taken on by extra-curricular student groups. These types of projects have given rise to an opportunity within one of the sections of the "Business Aspects for Engineers" course. Students are assigned to do a feasibility study on a particular sustainable energy project in which they perform a detailed business analysis of the project within a local or global context. A sample of the topics for the projects completed in the last two years are listed below:

- Solar Electric System Affordability and Feasibility in Arizona

- An Economic Analysis of Solar Power in Michigan

- Economic Analysis of Two Small Scale Wind Turbines in South Africa

- Geothermal Dorms at Calvin

- Wind Turbines On The Great Lakes

- Calvin Swimming Pool Solar Water Heating

- Recovery of Small Hydro Power Stations in Michigan

- Tidal Power Opportunities

- Polymer Solar Cells

- Bio Digesters at Calvin

- Wind Powered Computer Lab

- PV Power,

- Economic Analysis of Importation and Production of Sugarcane Ethanol in the US

- Feasibility of Domestic Renewables

- Renewable Energy Feasibility Study on Solar Water Heating

- Geothermal Heat Pumps for Residential Applications

- Calvin Gardens: Replacing Lawns with Gardens. 
The capstone senior design course is a two-course sequence taken during the students' final year. Student-formed design teams work on student-selected design projects through the fall and spring semesters. Faculty provide content through lectures and project guidance as managers of certain teams. Through our assessment data for the course, we have identified the following areas for improvement: 1) discussion of entrepreneurial mindset attributes, 2) presentations on literature sourcing, 3) presentations on patents and other forms of intellectual property, 4) an emphasis on quality management, 5) a focus on design for manufacturing when appropriate, and 6) an emphasis on the application of business accounting and management. One of our lead senior design faculty members will be working on the implementation of these changes.

An unexpected opportunity came up this year when a business strategies course offered to team up business students with some senior design teams. The business students helped the engineering teams assess and plan for the business aspects of the project. This association of courses provided some good cross-fertilization between teams. Plans are to continue the relationship with the business strategies course.

Following the successes seen in the changes made to courses at the beginning and end of the students' program, we will be investigating opportunities to incorporate business and entrepreneurship into some of the courses that students take in their second and third years. A pilot of this has taken place in some of the upper-level electrical/computer engineering courses with good success. Many of those classes already include design projects and by adding requirements such as cost analysis, marketability, etc, students have been more engaged by the real-world appeal those projects have.

Also, in some Junior and Senior levels courses, students are requested, in connection with their senior design projects, to produce brochures which take into account the marketing and other business aspects of their proposed products. Examples are illustrated in Figure 1.
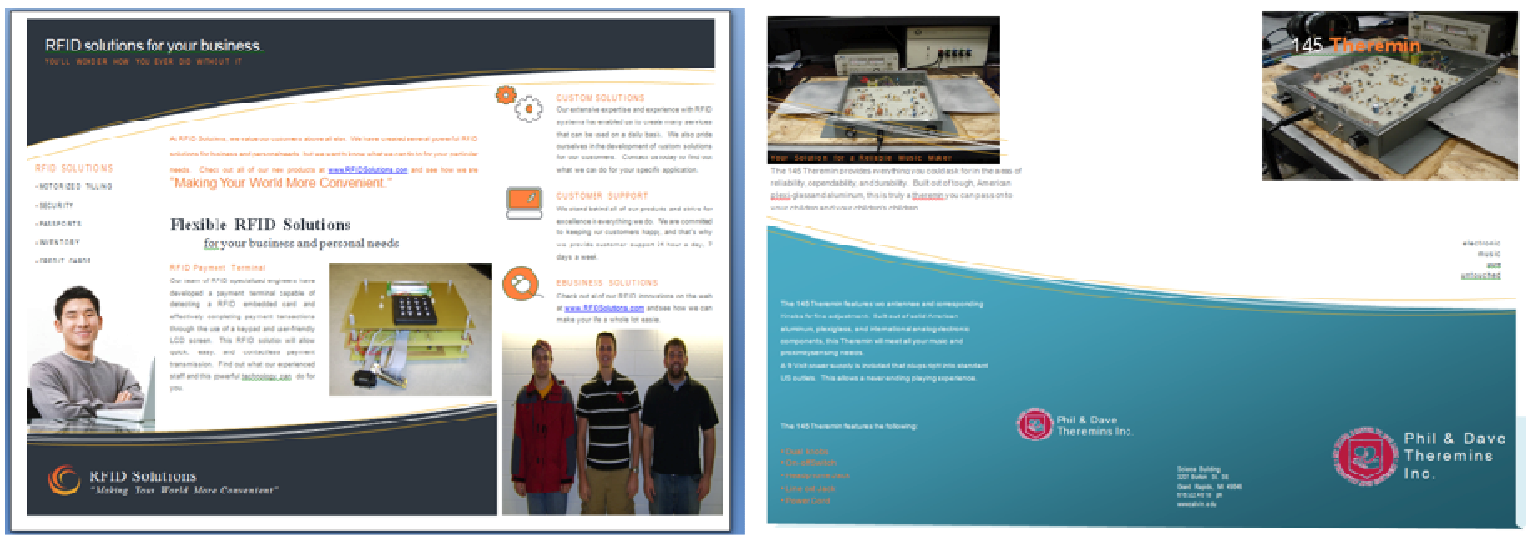

Figure 1. Examples of Student-Generated Marketing Brochures

The idea is to encourage students to actively take initiative, develop their own tastes and interests rather than regurgitate the textbook or the professor's rendering of the information. This encourages students to grow beyond the rather trivial art of simulating orthodox responses, creatively generating their own paths and ideas. 
The Engineering Department is currently analyzing our entire curriculum to review and clarify the specific outcomes and expectations of each course. To sustain the changes described above and any future changes, it is important to incorporate those entrepreneurial topics into the outcomes for each course as appropriate. Unless they are documented at that level, individual faculty may choose to skip such topics. This is often a difficulty with micro-insertion approaches: they get lost over time if accountability is not institutionalized.

\section{Advantages of a General Engineering Curriculum}

Engineering practice for many engineers has begun to move away from component-level design and testing to system-level integration and verification. As such, the skill set needed in the future is different from what was traditionally seen as proper training of an engineer. The general approach to engineering education has always emphasized the benefits of a broad education and its advantages throughout the career of the engineer compared to a narrow engineering education that trains students for entry-level tasks or highly specialized engineering work. The adaptability of a broadly educated engineer will help her respond to system-level challenges and rapidly evolving technology and thus will set her apart in the $21^{\text {st }}$ century.

One of the best ways to enhance a broad engineering education is to complement it with contextual knowledge which is associated with a liberal arts curriculum. Courses taken in nontechnical disciplines help students understand the societal relationships that underlie many of the engineering challenges they will encounter. It is far too easy to design a disaster unintentionally when the engineer fails to recognize the various implications of such technology within society. Unforeseen consequences are often the result of blind spots created by overly narrow, focused attention. Often, however, students have not matured enough to see the value of some of the non-technical subjects and engineering faculty must continue to help them appreciate those courses.

\section{E. Broad education provides motivation}

In previous generations, students were motivated to learn due to the authority of the teacher. But with today's information overload, students are asking the question, "Why is it important that I learn this?" Some of the best motivations for learning come from the use of real-world problems. When engineering exercises are based on real situations, students are more likely to become engaged in the topic as opposed to traditional rote learning based on canned homework problems. Students in a general engineering program with an extensive exposure to the liberal arts are more able to understand the interesting aspects of real world problems and teachers can leverage their broad knowledge. That is, technical knowledge supplies the "what", but the context usually supplies the "why" of a problem and its solution.

\section{F. $\quad$ Assessment}

Assessment of basic knowledge is far easier than assessment of a person's attitudes and values. We have been able to do some straightforward assessment of business/economic knowledge through course assessments, informal feedback, outcome-based rubrics, and standardized exam (e.g. FE exam) results. We have seen knowledge improvement in many areas from the changes we have implemented. Informally, we have also received feedback from students indicating they 
are more engaged in the topics, especially entrepreneurship, but also the technical topics seen from a vantage point of entrepreneurship.

The next steps for assessment of the changes is to formalize more outcome-based assessment at the course level, develop assessment before and after courses to measure cause and effect as much as possible, and to find a tool for assessing what a student values (mindset). The KEEN network has been working hard on addressing the assessment of the entrepreneurial mindset and has been exploring the use of some sophisticated tools such as the TTI TriMetrix assessment tool. Still, one of the biggest challenges of assessment is to gather the right useful information without burdening the students.

\section{Conclusion}

General/multidisciplinary engineering programs are designed to help students see the broad issues and big-picture aspects of engineering and are thus well-positioned to integrate the development of an entrepreneurial mindset in their students. Fitting new topics in very full programs is difficult. The engineering program at Calvin College is affecting all engineering students by using micro-insertions of entrepreneurial topics in a range of appropriate courses which are taken by every engineering student. Based on preliminary results, this approach has been successful, but better assessment is needed to understand the effect of these changes in our students.

\section{Bibliography}

\footnotetext{
${ }^{1}$ VanderLeest, S.H., "Biblical Principles for a Christian Engineering Entrepreneur," Proceedings of the 2009 Christian Engineering Education Conference, Waco, TX, June, 2009, pp. 10-22.

${ }^{2}$ Standish-Kuon, T. and Rice, M., "Introducing Engineering and Science Students to Entrepreneurship: Models and Influential Factors at Six American Universities" Journal of Engineering Education, Jan. 2002, pp. 33-39.

${ }^{3}$ Streeter, D. and Jaquette, J., "University-wide Entrepreneurship Education: Alternative Models and Current Trends," Southern Rural Sociology, v20, n2, 2004, pp. 44-71.

${ }^{4}$ Emery, K.A., Feland, J., "Educators Corner: A Response to Needs in Entrepreneurship Education," Proceedings of the American Society for Engineering Education Annual Conference 2002.

${ }^{5}$ Wang, E., and Kleppe, J., "Teaching Invention, Innovation, and Entrepreneurship in Engineering," Journal of Engineering Education, Oct. 2001, pp. 565-570.

${ }^{6}$ Creed, C.J., Suuberg, E., and Crawford, G. "Engineering Entrepreneurship: An Example of A Paradigm Shift in Engineering Education,” Journal of Engineering Education, v91, n2, April 2002, pp. 185-195.

${ }^{7}$ Ohland, M., et.al., "Nine Approaches to Including Multidisciplinary Design in the Curriculum", Proceedings of the International Conference on Engineering Education (ICEE) 1999, University of Ostrava, August 10-14, 1999, http://www.fs.vsb.cz/akce/1999/icee99/Proceedings/papers/340/340.htm

${ }^{8}$ The Enterprise Program. Michigan Technological University, Houghton, MI.

http://www.enterprise.mtu.edu

${ }^{9}$ The Interprofessional Projects Program, Illinois Institute of Technology, Chicago, IL. http://ipro.iit.edu/

${ }^{10}$ Marchese, A.J., Schmalzel, J.L., and Weaver, K.M., "Creating an Entrepreneurial Culture at a Startup Engineering Program," Proceedings of the American Society for Engineering Education Annual Conference 2004.

${ }^{11}$ Fredholm, S., et. al , "Designing an Engineering Entrepreneurship Curriculum for Olin College," Proceedings of the American Society for Engineering Education Annual Conference 2002.
} 